\title{
Transmission of white sturgeon iridovirus in Kootenai River white sturgeon Acipenser transmontanus
}

\author{
John D. Drennan ${ }^{1}$, Scott E. LaPatra ${ }^{2}$, Jack T. Siple ${ }^{3}$, Sue Ireland ${ }^{3}$, Kenneth D. Cain ${ }^{1}{ }^{*}$ \\ ${ }^{1}$ Department of Fish and Wildlife Resources and the Aquaculture Research Institute, University of Idaho, Moscow, \\ Idaho 83844-1136, USA \\ ${ }^{2}$ Clear Springs Foods, Inc., PO Box 712, Buhl, Idaho 83316, USA \\ ${ }^{3}$ Kootenai Tribe of Idaho, PO Box 1269, Bonners Ferry, Idaho 83805, USA
}

\begin{abstract}
It is thought that white sturgeon iridovirus (WSIV) is transmitted vertically from adult white sturgeon Acipenser transmontanus to progeny, and that wild adults are carriers of this virus. Based on this assumption, egg disinfection trials were initiated using wild Kootenai River white sturgeon. Over 2 consecutive years, post-fertilized eggs were disinfected with iodine at concentrations ranging from 0 to $400 \mathrm{ppm}$. Eggs were incubated and progeny were reared on either de-chlorinated municipal or Kootenai River water. Juvenile sturgeon (mean weight $3.0 \mathrm{~g}$ ) from these treatment groups were then subjected to a density stress (15 or $20 \mathrm{~g} \mathrm{l}^{-1}$ ) to manifest WSIV disease in individuals harboring the virus. In Year 1, mortality in all groups ranged from 6 to $37 \%$ and the use of municipal water was shown to significantly improve survival. However, WSIV infection was not detected in fish from any of the treatment groups or controls, and therefore did not contribute to the observed mortality. In Year 2, all treatment and control groups reared on Kootenai River water tested positive for WSIV infection and exhibited mortality ranging from 59 to $94 \%$, but fish from groups reared on municipal water did not test positive for WSIV infection. This shows that that vertical transmission did not occur in this study. Horizontal transmission played a significant role in WSIV infection, but the lack of infection in Year 1 suggests a cyclic occurrence of the virus in the Kootenai River system. Although survival tended to be better in iodine-treated groups, the effects of iodine treatment in relation to WSIV transmission remain unknown. An important finding is that not all wild white sturgeon broodstock yield WSIV-positive progeny.
\end{abstract}

KEY WORDS: Sturgeon · White sturgeon iridovirus · WSIV · Transmission · Egg disinfection

\section{INTRODUCTION}

White sturgeon iridovirus (WSIV) appears to be enzootic in the Kootenai River white sturgeon Acipenser transmontanus population as well as in other wild sturgeon populations in the Pacific Northwest USA (LaPatra et al. 1994). The Kootenai Tribe of Idaho (KTOI) sturgeon enhancement hatchery, located near the Kootenai River and Bonners Ferry, Idaho, experienced its first WSIV epizootic during November 1992, resulting in $52 \%$ mortality (LaPatra et al. 1999). Histological examination of the gills and skin of 6 mo old juveniles that had died indicated cellular changes typical of WSIV. The epizootic was likely due to high rearing density, excessive handling, and a temporary loss of water, which created a stressful environment that is known to induce WSIV disease in sturgeon harboring the virus (LaPatra et al. 1994, LaPatra et al. 1996, Georgiadis et al. 2001). Since then, the hatchery has altered the husbandry practice of sturgeon younger than 1 yr of age by minimizing handling and improving water quality, which has reduced the incidence of WSIV disease outbreaks.

Prior to the release of juveniles into the Kootenai River system in 1997, an annual pathogen-screening program 
was implemented by the hatchery. Although no viral or bacterial pathogens were detected using standard culture procedures, histological examinations of fin epithelial tissue revealed $40 \%$ prevalence of cellular changes typical of WSIV infection. These annual inspections have detected WSIV infection in 1997, 2000, 2001, 2003, and 2004 year-class sturgeon (K. Clemens, United States Fish and Wildlife Service, Idaho Fish Health Center, pers. comm.). This suggests that the virus is enzootic to the Kootenai River and sturgeon reared on river water are susceptible to infection.

Disease caused by WSIV is characterized as a slow chronic wasting syndrome that typically affects juvenile white sturgeon in the first year of growth (Hedrick et al. 1990). Mortality associated with WSIV is assumed to be due to anorexia, respiratory dysfunction, failure to maintain osmoregulation, and secondary microbial infection (Watson et al. 1998).

A recent study from our laboratory using 2001 yearclass sturgeon from the KTOI hatchery demonstrated a correlation between high density rearing and the manifestation of WSIV disease in sturgeon harboring the virus (Drennan et al. 2005). Stocking of asymptomatic sturgeon (mean weight $4.2 \mathrm{~g}$ ) at initial rearing densities of $13 \mathrm{~g} \mathrm{l}^{-1}$ can act as a stressor to provoke clinical disease, which results in mortality at approximately $30 \mathrm{~d}$ at a water temperature of $15^{\circ} \mathrm{C}$. Similar evidence for the occurrence of WSIV epizootics in association with high-density rearing of juvenile white sturgeon has been observed (LaPartra et al. 1996).

The virus has been shown to be capable of causing fatal infection in white sturgeon following bath exposure (Hedrick et al. 1992, Watson et al. 1998). Horizontal transmission of WSIV from infected individuals to healthy fish has also been demonstrated (Hedrick et al. 1990). Past studies and observations suggest that the virus may be vertically transmitted from adult to offspring during spawning (Hedrick et al. 1992, LaPatra et al. 1994, Georgiadis et al. 2001). Conversely, there may be genetic differences among some stocks of fish that have increased resistance or susceptibility to WSIV infection, making observations of vertical transmission more confusing. An epidemiological study of the risk factors associated with mortality caused by WSIV suggested that the spawning of different broodstock mating pairs attributed to differences in susceptibility of progeny to infection (Georgiadis et al. 2000).

Iodine-based disinfectants (e.g. Wescodyne or Argentyne) are commonly used in trout and salmon aquaculture programs and have been shown to eliminate or reduce transmission of egg-surface-associated pathogens (Amend \& Pietsch 1972). Current applications involve disinfection of eggs for 10 min or longer at a concentration of 100 ppm of iodine. Fish pathogens such as infectious hematopoeitic necrosis virus (IHNV) and the bacterium Aeromonas salmonicida have been shown to be egg-surface-transmitted but not intraovum (Goldes \& Mead 1995, Cipriano et al. 2001). Consequently, egg surface disinfection reduces disease outbreaks caused by these infectious agents. In addition, surface disinfection of eggs with ozonated seawater and/or iodine has also been shown to efficiently prevent the transmission of viral encephalopathy and retinopathy (VER) and striped jack nervous necrosis virus (Arimoto et al. 1996, Grotmol \& Totland 2000). In contrast, the use of iodine disinfection of eggs is not effective at minimizing disease transmission when pathogens such as infectious pancreatic necrosis virus (IPNV) or Renibacterium salmoninarum are involved, since these have been shown to be transmitted intraovum (Bootland et al. 1991, Bullock et al. 1976).

In this study, 2 experiments were conducted over consecutive years (2002 and 2003) to address the question of whether WSIV is transmitted vertically from adult broodstock to progeny via the egg, and if so, whether the virus transmitted is on the egg-surface or intra-ovum. This was accomplished by the use of iodine disinfection of post-fertilized eggs. It was hypothesized that iodine disinfection of eggs using established procedures would reduce egg-surface-associated transmission of WSIV and could be a prudent management tool in the culture of white sturgeon.

\section{MATERIALS AND METHODS}

Fish. White sturgeon used in Expt 1 (2002) and in Expt 2 (2003) were obtained as eggs from the KTOI hatchery. In both years, post-fertilized de-adhezed eggs from 1 mating pair were obtained immediately following spawning of wild adult broodstock. Eggs were separated into treatment groups of approximately 2000 each and subjected to 10 min iodine bath incubations. In Expt 1, egg treatment groups received either 100, 200, or $400 \mathrm{ppm}$ of iodine. In Expt 2, egg treatment groups received either 100 or $200 \mathrm{ppm}$ of iodine. Control groups received no iodine bath incubation $(0 \mathrm{ppm})$. Argentyne (Argent Chemical Laboratories) was used as the iodine-based solution and was diluted to the appropriate active iodine concentration (ppm) using de-chlorinated municipal water (total hardness approximately $119 \mathrm{mg} \mathrm{l}^{-1}$ ) and to a final $\mathrm{pH}$ of 7.0. Following disinfection, eggs from each treatment group were rinsed with de-chlorinated municipal water, and either maintained on Kootenai River water at the KTOI hatchery or transported to the University of Idaho (UI) to be hatched and reared on de-chlorinated municipal water. During fertilization and iodine treatment, eggs were never exposed to Kootenai River water. All treatment groups at each facility were 
kept isolated and reared to approximately 4 mo of age before being subjected to high-density rearing (Table 1).

High-density rearing. Juvenile sturgeon from each treatment group were subjected to high-density rearing conditions to elicit WSIV disease in fish that were harboring the virus (LaPatra et al. 1996, Drennan et al. 2005). Sturgeon from iodine treatment groups that had been maintained at the KTOI hatchery were transported to the UI aquaculture facility for this portion of the study. These fish were acclimated for $14 \mathrm{~d}$ prior to high-density rearing.

In Expt 1, juvenile sturgeon (mean weight $3.0 \mathrm{~g}$ ) were stocked into experimental units consisting of 41 flow-through tanks with air-stones for oxygenation. Each treatment group was stocked in triplicate at a density of $20 \mathrm{~g} \mathrm{l}^{-1}$ resulting in approximately 26 fish $\operatorname{tank}^{-1}$. Water temperature averaged $12^{\circ} \mathrm{C}$ throughout the duration of the study and inflow rates were set to 6.6 exchanges $\mathrm{h}^{-1}$. Dissolved oxygen was monitored throughout the experiment and averaged $8.20 \mathrm{mg} \mathrm{l}^{-1}$. Sturgeon were fed a commercial diet (Rangen) at 2 to $4 \%$ body weight $\mathrm{d}^{-1}$.

In Expt 2, juvenile sturgeon (mean weight $2.6 \mathrm{~g}$ ) from each treatment group were stocked in triplicate at a density of $15 \mathrm{~g} \mathrm{l}^{-1}$, resulting in an average of 24 fish tank $^{-1}$. Water temperature averaged $12^{\circ} \mathrm{C}$ and inflow water rate was decreased to 2 exchanges $h^{-1}$. No air stones were incorporated in the tanks and dissolved oxygen remained $\geq 7.00 \mathrm{mg} \mathrm{l}^{-1}$ throughout the study.

In each experiment, progeny were generated from 1 parental cross that consisted of 1 female and 1 male fish. However, we felt that the involvement of a different male cross to the same female fish may provide information on whether vertical transmission of WSIV via the milt was occurring during fertilization. There-

Table 1. Acipenser transmontanus. Treatment groups of juvenile white sturgeon used for Expt 1 and Expt 2

\begin{tabular}{|ccc|}
\hline & $\begin{array}{c}\text { Treatment groups } \\
\text { (Iodine conc. of } \\
\text { egg disinfection) }\end{array}$ & $\begin{array}{c}\text { Rearing water } \\
\text { source }\end{array}$ \\
\hline Expt 1 (2002) & $400 \mathrm{ppm}$ & Municipal \\
& $200 \mathrm{ppm}$ & Municipal \\
& $100 \mathrm{ppm}$ & Municipal \\
& No iodine (control) & Municipal \\
& No iodine (control) & Kootenai River \\
Expt 2(2003) & $200 \mathrm{ppm}$ & Municipal \\
& $100 \mathrm{ppm}$ & Municipal \\
& No iodine (control) & Municipal \\
& $100 \mathrm{ppm}$ & Kootenai River \\
& No iodine (control) & Kootenai River \\
& Family 1B54 & Kootenai River \\
& Family 403F & Kootenai River \\
\hline
\end{tabular}

fore, in Expt 2, approximately 150 juvenile sturgeon (mean weight $2.1 \mathrm{~g}$ ) denoted as family 1B54 were included in the study. These fish were generated through fertilization with milt from a different male (1B54) with the eggs from the same brood-female as all previously mentioned treatment groups in Expt 2 . Additionally, progeny from family 403F (mean weight $2.6 \mathrm{~g}$ ) that were generated from a different single mating pair cross were also included in this study.

Waterborne transmission of WSIV. Following the $80 \mathrm{~d}$ high-density rearing trial in Expt 2, a waterborne transmission study was conducted. This would provide further support that sturgeon originally hatched and reared on de-chlorinated municipal water were not harboring WSIV by demonstrating susceptibility to WSIV infection following exposure to the virus. This study would also confirm the susceptibility of naïve sturgeon to horizontal transmission of WSIV from naturally-infected sturgeon in the absence of fish-to-fish contact.

The experimental units for this study consisted of two 41 flow-through tanks where the lower tank was connected to the upper tank by a rubber tube. This allowed water from the upper tank to drain into the lower tank at a rate of $5 \mathrm{l} \mathrm{h}^{-1}$. Both tanks had inflow dechlorinated water adjusted to $16 \mathrm{l} \mathrm{h}^{-1}$ supplemented with air-stones. Sturgeon survivors reared on municipal water (mean weight $8.1 \mathrm{~g}$ ) from each treatment replicate (i.e. 0, 100, or $200 \mathrm{ppm}$ ) of the high-density rearing trial were removed from their triplicate tanks, pooled, and a portion of the individuals were randomly stocked into 1 of 3 lower tanks at $26 \mathrm{~g} \mathrm{l}^{-1}$ (13 fish tank $\mathrm{k}^{-1}$ ). This corresponds to the placement of survivors from the $200 \mathrm{ppm}, 100 \mathrm{ppm}$, and 0 ppm groups into lower tanks \#1, \#2, and \#3, respectively. Upper tanks were stocked with asymptomatic, WSIV-infected white sturgeon (mean weight $1.4 \mathrm{~g}$ ). These fish were additional progeny from family 1B54 that were obtained from the KTOI hatchery and confirmed to be infected with WSIV by histological examination. After transport, fish were placed in the upper tanks \#1, \#2, and \#3 at an initial stocking density of $5.5 \mathrm{~g} \mathrm{l}^{-1}$ (16 fish tank $\mathrm{k}^{-1}$ ). Control groups (in triplicate) were stocked at $26 \mathrm{~g} \mathrm{l}^{-1}$ (13 fish tank ${ }^{-1}$ ), with sturgeon reared on municipal water (0 ppm iodine disinfection) in the lower tanks and no fish stocked in the upper tanks.

During the high-density rearing experiments and the waterborne transmission study, fish were observed for 80 d. In Expt 1, all dead and moribund fish were removed daily and processed for histological examination. In Expt 2 and the waterborne transmission study, dead and moribund fish were removed daily and a minimum of $20 \%$ of the fish $\mathrm{d}^{-1}$ were processed for histological examination. For control groups of the waterborne transmission study, $20 \%$ of the fish were 
randomly selected at the termination of the study for detection of WSIV. The mean cumulative percent mortality (CPM) was calculated for all replicates.

WSIV confirmation. Histology: Moribund and dead sturgeon were fixed in neutral buffered formalin $(10 \%$ formalin, $45 \mathrm{mM} \mathrm{Na}_{2} \mathrm{HPO}_{4}, 33 \mathrm{mM} \mathrm{NaH} \mathrm{PO}_{4}$ ) for at least $48 \mathrm{~h}$ prior to histological processing. To observe epithelial tissue and gills, heads were cut sagittally producing 2 halves using a scalpel. Histology cassettes containing half-heads were then submitted to the Washington Animal Disease and Diagnostic Laboratory for further processing and paraffin embedding. Sections of 3 to $5 \mu \mathrm{m}$ were cut and stained using hematoxylin and eosin following standard procedures. Processing for the diagnosis of other possible disease agents was not done.

Electron microscopy: To further confirm the presence of WSIV infection, skin tissues from a portion of moribund white sturgeon were processed for electron microscopy. Samples were fixed in $2 \%$ glutaraldehyde $+2 \%$ paraformaldyde in $0.1 \mathrm{M}$ cacodylate buffer ( $\mathrm{pH} 7.4$ ) and post fixed in $2 \% \mathrm{OsO}_{4}$ in $0.1 \mathrm{M}$ cacodylate buffer $(\mathrm{pH}$ 7.4). Following dehydration with ethyl alcohol, samples were infiltrated and embedded in Spurr's resin. Ultra-thin $(100 \mathrm{~nm})$ sections were cut and stained with $4 \%$ uranyl acetate and Reynolds's lead. Tissues were examined using a JEOL 1200 EX transmission electron microscope (TEM) at $100 \mathrm{kV}$. Digital imaging was performed with a SOFT Imaging Systems camera and AnalySIS software (Soft Imaging System Corp).

Statistical analysis. Statistical significance of CPM among treatment groups was assessed by 1-way ANOVA using GraphPad Prism statistical software (GraphPad Software). Additional analysis of significant differences was performed using paired comparisons between treatment groups using Tukey's test. Values were considered significantly different at p-values $<0.05$.

\section{RESULTS}

\section{High-density rearing to manifest WSIV disease}

\section{Expt 1}

In the no iodine treatment group originally reared on Kootenai River water, $37 \%$ mortality was observed after $80 \mathrm{~d}$. This differed significantly $(\mathrm{p}<0.05)$ from all of the iodine treated groups (Table 2). Treatment groups reared in municipal water and disinfected with 400 ppm, 200 ppm, and 100 ppm iodine experienced mortality of $6 \%, 8 \%$, and $10 \%$, respectively. Mortality of $22 \%$ was observed in the no iodine treated group
Table 2. Acipenser transmontanus. Expt 1 (2002): cumulative percent mortality (CPM) of white sturgeon (mean weight $3.0 \mathrm{~g}$ ) following high-density rearing $\left(20 \mathrm{~g} \mathrm{l}^{-1}\right)$ for $80 \mathrm{~d}$. WSIV infection not identified in fish from any treatment groups. ${ }^{a, b}$ significant differences $(p<0.05)$ in mean CPM

\begin{tabular}{|lcc|}
\hline $\begin{array}{l}\text { Rearing water } \\
\text { source }\end{array}$ & $\begin{array}{c}\text { Treatment } \\
\text { (Iodine conc. of } \\
\text { egg disinfection) }\end{array}$ & CPM $\pm \mathrm{SD}$ \\
\hline Municipal & $400 \mathrm{ppm}$ & $6.1 \pm 2.6^{\mathrm{a}}$ \\
& $200 \mathrm{ppm}$ & $7.9 \pm 11.6^{\mathrm{a}}$ \\
& $100 \mathrm{ppm}$ & $9.9 \pm 6.2^{\mathrm{a}}$ \\
Kootenai River & No iodine & $21.7 \pm 10.5^{\mathrm{ab}}$ \\
& No iodine & $37.3 \pm 9.4^{\mathrm{b}}$ \\
\hline
\end{tabular}

reared on municipal water. This group did not differ significantly from any of the other treatment groups. Although diagnostic screening for the presence of other pathogens was not performed, histological examination of all moribund and dead fish did not identify cellular changes typical of WSIV infection from any of the treatment groups, indicating that WSIV did not contribute to mortality.

\section{Expt 2}

WSIV infection was detected and differences in mortality between treatment groups and additional families (1B54 and 403F) were observed. All treatment groups and families reared on Kootenai River water exhibited increased mortality following high-density rearing. Histological examination of the skin and gills from fish in these groups identified hypertrophied basophilic stained cells within the epithelia typical of WSIV infection (Fig. 1). In addition, numerous virus particles were observed by electron microscopy (Fig. 2). The icosahedral shape, double capsid formation, dense nucleoid center, and size (250 to $300 \mathrm{~nm}$ ) of virions observed were all characteristic of the virus (Hedrick et al. 1990, Hedrick et al. 1992, Watson et al. 1998). WSIV was not detected in any treatment groups reared on de-chlorinated municipal water, except for 1 of the triplicate tanks (tank \#16) of the 100 ppm iodine treatment group. This observation appeared strongly linked to a contamination event that occurred when additional fish were transported to the UI from the KTOI hatchery on October 31, 2003. During stocking of these fish into nearby tanks, approximately $100 \mathrm{ml}$ of Kootenai River water accidentally spilled into tank \#16 and was noted at the time. Subsequently, sturgeon transported from KTOI on that day tested positive for WSIV and the first moribund sturgeon in tank \#16 to test positive for WSIV occurred $41 \mathrm{~d}$ later. A total of 6 


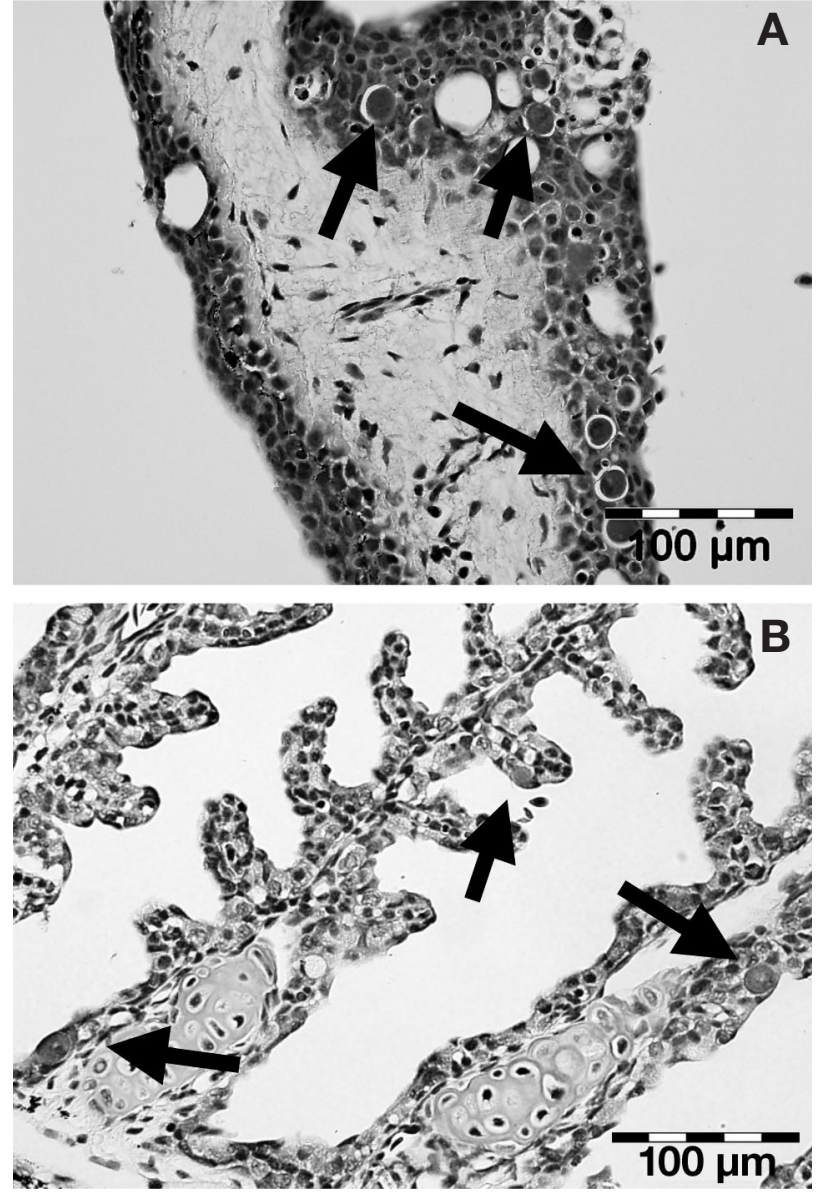

Fig. 1. Acipenser transmontanus. Light micrograph of hematoxylin and eosin stained sections showing enlarged basophilic stained cells (arrows) within the epithelium of the skin (A) and gills (B) typical of WSIV infection. Scale bars $=100 \mu \mathrm{m}$

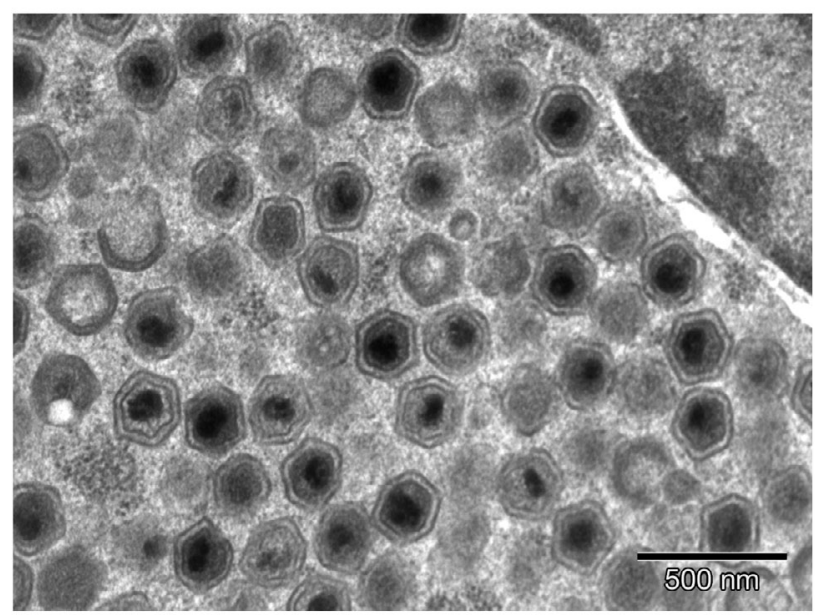

Fig. 2. Acipenser transmontanus. Transmission electron micrograph of skin tissue from white sturgeon reared on Kootenai River water showing ultrastructural details of WSIV particles. Scale bar $=500 \mathrm{~nm}$ moribund/mortalities occurred in tank \#16 during the $80 \mathrm{~d}$ high-density rearing study. Of these 6 fish sampled for histological examination, only the last 2 mortalities - occurring on Day 62 and 66 of the studytested positive for WSIV infection.

All treatment groups reared on municipal water experienced low mortality (Fig. 3), similar to results obtained from Expt 1 (2002). These groups of fish continued to feed and appeared healthy throughout the duration of the study. The lowest mortality (5.6\%) occurred in the $200 \mathrm{ppm}$ iodine treated group. The $100 \mathrm{ppm}$ and control groups resulted in cumulative mortalities of $15.4 \%$ and $14.5 \%$, respectively.

Fish from treatment groups transported from the KTOI hatchery (reared on river water) did not exhibit signs of WSIV disease during the $14 \mathrm{~d}$ acclimation

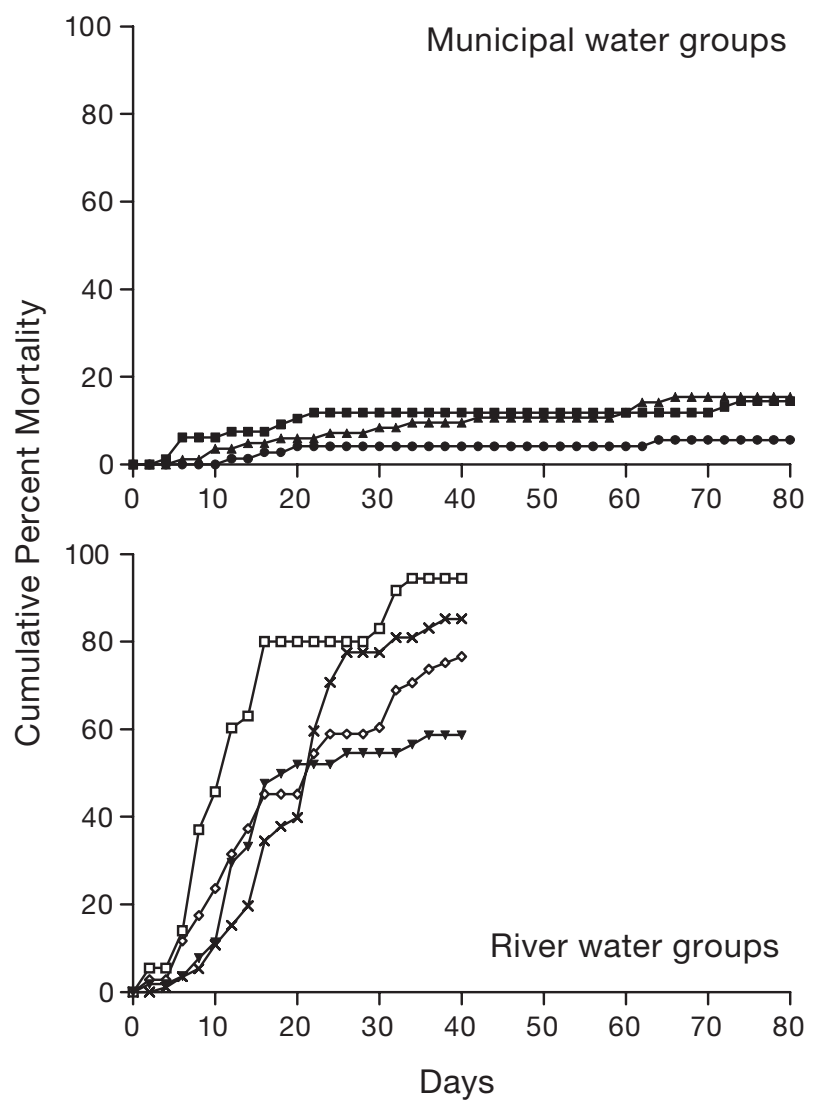

Fig. 3. Acipenser transmontanus. Expt 2 (2003) cumulative percent mortality (CPM) of white sturgeon originating from eggs disinfected with various concentrations of iodine (ppm) and reared on either de-chlorinated municipal water $[0 \mathrm{ppm}$

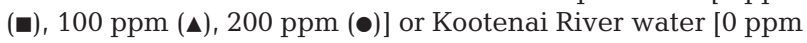
(), $100 \mathrm{ppm}(\mathbf{\nabla})]$. Additional sturgeon family groups reared on Kootenai River water [family 1B54 ( $\times$ ) and family 403F $(\diamond)$ ] were also included. Fish from these groups were subjected to high-density rearing $\left(15 \mathrm{~g} \mathrm{l}^{-1}\right)$ for either 80 or $40 \mathrm{~d}$ at the University of Idaho aquaculture facility on municipal water. Mean values are shown for 3 replicates 
period but did appear lethargic. When placed under high-density rearing conditions, mortality started to occur in all groups by Day 3 and continued to increase throughout the study. Fish continued to appear lethargic, discontinued feeding, and showed an increase in respiratory activity (gilling). Some of the mortalities displayed hemorrhaging around the base of fins and mouth. Mortality ranged from 59 to $94 \%$ at $40 \mathrm{~d}$ poststocking, and this portion of the study was terminated at that time.

Cumulative percent mortality observed in the $200 \mathrm{ppm}$ treated group reared on municipal water differed significantly $(\mathrm{p}<0.001)$ from all river water treatment groups. Groups treated with $100 \mathrm{ppm}$ and no iodine and reared on municipal water were also significantly different $(p<0.05)$ from the groups reared on river water. There were no statistically significant differences in CPM among groups reared on river water after $40 \mathrm{~d}$, although cumulative mortality was lowest $(58.7 \%)$ in the iodine treated group (Table 3$)$.

\section{Waterborne transmission}

Sturgeon known to be infected with WSIV were stocked into upper tanks \#1, \#2, and \#3. One sturgeon from both upper tank \#1 and \#2 died within a few hours of stocking and, by Day 14, an additional 3 mortalities occurred between upper tanks \#2 and \#3. Histological examination of these fish indicated the presence of cellular changes within the epithelium typical of WSIV infection. Mortality increased in these tanks by Day 18 and continued through Day 66 resulting in 81,94 , and $88 \%$ in upper tank \#1, \#2, and \#3, respectively (Fig. 4).

The first moribund sturgeon removed from the lower tanks (receiving water from upper tanks) occurred after $10 \mathrm{~d}$ and was from lower tank \#2. The fish showed

Table 3. Acipenser transmontanus. Expt 2 (2003): cumulative percent mortality (CPM) of white sturgeon following highdensity rearing. WSIV was detected only in fish reared on Kootenai River water. ${ }^{a, b}$ significant differences $(p<0.05)$ in mean CPM

\begin{tabular}{|lcc|}
$\begin{array}{l}\text { Rearing water } \\
\text { source }\end{array}$ & $\begin{array}{c}\text { Treatment groups } \\
\text { (Iodine conc. of } \\
\text { egg disinfection) }\end{array}$ & CPM $\pm \mathrm{SD}$ \\
\hline Municipal & $200 \mathrm{ppm}$ & $5.6 \pm 2.4^{\mathrm{a}}$ \\
& $100 \mathrm{ppm}$ & $15.4 \pm 6.0^{\mathrm{a}}$ \\
Kootenai River & No iodine (control) & $14.5 \pm 11.9^{\mathrm{a}}$ \\
& 100 ppm & $58.7 \pm 21.3^{\mathrm{b}}$ \\
& No iodine (control) & $94.5 \pm 7.9^{\mathrm{b}}$ \\
& Family 403F & $76.6 \pm 17.7^{\mathrm{b}}$ \\
& Family 1B54 & $85.2 \pm 12.8^{\mathrm{b}}$ \\
\hline
\end{tabular}

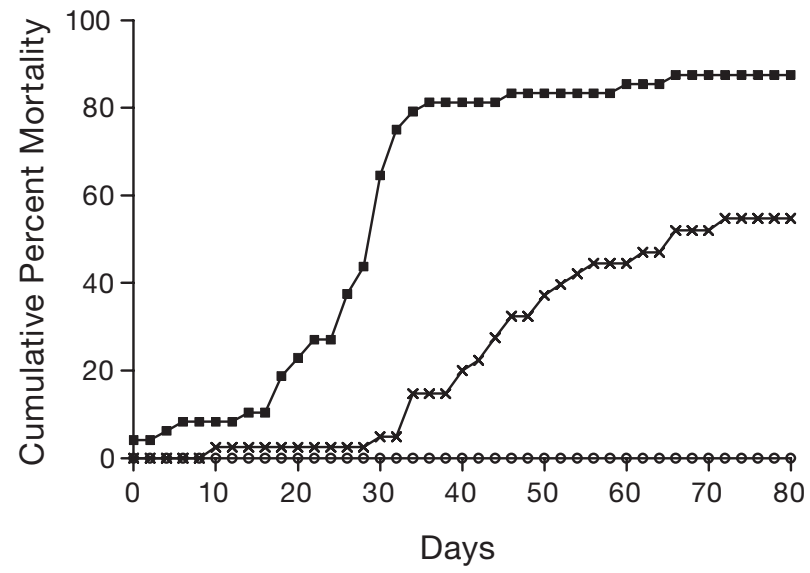

Fig. 4. Acipenser transmontanus. Susceptibility of municipal water-reared sturgeon to waterborne transmission of WSIV. Following $80 \mathrm{~d}$ high-density rearing (Expt 2), sturgeon (mean weight $8.1 \mathrm{~g}$ ) from each municipal water-reared treatment group ( $\mathrm{x}$ ) were stocked at $26.2 \mathrm{~g} \mathrm{l}^{-1}$ in $4 \mathrm{l}$ tanks and exposed to water $\left(5 \mathrm{l} \mathrm{h}^{-1}\right)$ from tanks stocked with asymptomatic WSIV infected white sturgeon (घ) (5.5 $\mathrm{g} \mathrm{l}^{-1}$; mean weight $1.4 \mathrm{~g}$ ). Control group (o) consisted of municipal water-reared sturgeon stocked at $26.2 \mathrm{~g} \mathrm{l}^{-1}$ that were not exposed to water from asymptomatic white sturgeon, in triplicate. CPM was monitored for $80 \mathrm{~d}$

no signs of WSIV disease and histological examination did not identify a WSIV infection. Additional mortality in the lower tanks started to occur approximately $30 \mathrm{~d}$ post-stocking. Sturgeon from lower tanks \#1 and \#2 discontinued feeding around $20 \mathrm{~d}$ post-stocking. Fish became lethargic, emaciated, and an increase in respiratory activity was observed. These signs were not as apparent in lower tank \#3 until $72 \mathrm{~d}$ after initiation of the study. Completion of the $80 \mathrm{~d}$ exposure resulted in mortality of $79 \%, 69 \%$, and $25 \%$ in the lower tanks \#1, $\# 2$, and \#3, respectively. All moribund/dead sturgeon from the lower tanks were processed for histological examination and WISV infection was confirmed. No mortalities occurred within the triplicate tanks containing the controls, and histological examination showed no evidence of WSIV infection.

\section{DISCUSSION}

This study was designed to determine whether eggassociated transmission of WSIV occurs, and if so, whether iodine disinfection of post-fertilized eggs would be an effective management strategy to inhibit or reduce this route of viral transmission. Results from Expt 2 (2003) showed that all fish reared from eggs on Kootenai River water (either iodine disinfected or not) tested positive for WSIV infection and exhibited increased mortality when subjected to high-density 
rearing conditions. However, juvenile white sturgeon from the same family cross, and (1) hatched from eggs either iodine disinfected or not and (2) held on de-chlorinated municipal water, did not exhibit signs of WSIV disease. Pathognomonic changes typical of WSIV infection were not identified following histological examination except for 1 contamination event. These results suggest that egg-associated transmission of WSIV did not occur and that the primary mode of transmission of this virus at the Kootenai hatchery in this study was horizontal or waterborne.

It is well established that egg disinfection is an effective management strategy for minimizing many disease outbreaks. Since this study did not demonstrate egg-associated transmission of WSIV, a correlation between iodine disinfection of eggs and a reduction of WSIV related mortality could not be made. However, implementing such strategies may reduce transmission of other potential disease causing pathogens. Iodine disinfection of white sturgeon eggs has previously been shown to have no significant effect on hatch survival (Yesaki et al. 2002). Our findings support this. The iodine treated groups in Expt 1 (2002) had significantly better survival during high-density rearing when compared to sturgeon receiving no iodine treatment, whether reared on municipal water or river water. Similarly, lower CPM was observed in Expt 2 (2003) in the 100 ppm iodine treated group compared to controls originally reared on river water following high-density rearing. Although the specific factors responsible for such mortality differences were not evaluated, the observations suggest that iodine disinfection of eggs may be beneficial and may enhance overall survival of juvenile sturgeon.

The ability to induce WSIV disease in sturgeon reared on municipal water was demonstrated during the waterborne transmission study. These fish showed no signs of virus infection during the $80 \mathrm{~d}$ high-density rearing portion of Expt 2, which strongly suggests that these fish were not infected with virus. Because these fish did not have the added stressor of being transported prior to being subjected to high-density rearing conditions, as did the river-reared groups, there was some speculation that they were not as susceptible to WSIV. However, the results from this study demonstrate that these fish were susceptible to WSIV infection, resulting in morbidity and mortality, when exposed to virus. The waterborne transmission experiment also demonstrates the occurrence of horizontal transmission of WSIV from infected sturgeon to naïve sturgeon through the water column. Hedrick et al. (1990) showed horizontal transmission of WSIV in which naïve sturgeon exposed to infected fish died $40 \mathrm{~d}$ post-exposure. Both of these studies and the accidental contamination event of tank \#16 suggest WSIV is highly transmissible within the water, and caution should be used when transferring sturgeon with a known WSIV history. Not only should sturgeon be treated in a bio-secure manner, but also the water used for transport should be considered a contaminating source of virus.

Results from this study suggest egg-associated transmission of WSIV may not be routine in wild populations, and the use of an alternative water source other than the Kootenai River would likely minimize WSIV infection and disease outbreaks at the KTOI hatchery. Interestingly, failure to identify WSIV infection in sturgeon reared on municipal water supports previous observations made within this enhancement program. Currently, as a fail-safe method to ensure that no catastrophic losses occur to valuable Kootenai River white sturgeon, some of the fertilized eggs are reared at a different hatchery. During the spawning season, wild adult sturgeon are collected from the Kootenai River to obtain and fertilize gametes. Progeny are reared at the KTOI hatchery for 1 to $2 \mathrm{yr}$ and released back into the river. Additionally, a portion of the fertilized eggs from up to 5 families are transported to the British Columbia Kootenay Sturgeon Hatchery (KSH) located in Fort Steele, British Columbia, Canada for rearing. Prior to the transport, fertilized eggs are disinfected with $100 \mathrm{ppm}$ iodine for $10 \mathrm{~min}$ and then rinsed with water originating from the $\mathrm{KSH}$ hatchery. The water source that is used for rearing fish at this hatchery is virus-free groundwater. To date, this hatchery has not observed WSIV disease even though these sturgeon are siblings of families also reared at KTOI hatchery. This observation is similar to previous findings where the occurrence of WSIV infections can be detected among cultured white sturgeon reared on river water (Columbia River) but not detected among fish cultured in spring water (LaPatra et al. 1994).

These observations suggest that the source of WSIV is from some component within the river system and horizontal transmission of the virus is occurring. However, other studies where juvenile sturgeon testing positive for WSIV infection were cultured in spring water or well water suggest that egg-associated transmission (vertical) may have occurred (LaPatra et al. 1994, Georgiadis et al. 2001). Identifying infections in adult fish has proven difficult. In 1997, the KTOI performed a histological survey on opercular and dorsal fin biopsy tissues from 20 wild adult white sturgeon not used in the hatchery and 14 that were held in the hatchery for spawning. All tissue samples were negative for WSIV infection (S. Ireland, KTOI, pers. comm.). Whether or not wild adult broodstock are carriers of WSIV still remains to be substantiated. The application of more sensitive diagnostic tests, such as PCR, should enhance our ability to detect carriers and further 
address whether vertical transmission can occur and what role it plays in WSIV persistence among these and other sturgeon populations.

Although not evaluated in this study, it may be possible that an unidentified reservoir of WSIV exists within the river. The KTOI hatchery currently conducts annual inspections to screen for the presence of WSIV in juvenile white sturgeon obtained from their broodstock spawning program. Over the past $5 \mathrm{yr}$, WSIV infections have been detected in a portion of the progeny in every year except 2002. The absence of WSIV in 2002 is interesting since the hatchery uses a river water source. This suggests a cyclic nature to viral presence in the environment. It has been demonstrated that other viruses of the family Iridoviridae have the ability to infect multiple fish hosts and different taxonomic classes of animals. Lymphocystis disease virus has been shown to infect a variety of marine and freshwater fish species (Wolf 1988). Moody \& Owens (1994) have shown that the Bohle iridovirus (BIV), which is pathogenic to several species of amphibians, has the ability to be pathogenic in barramundi Lates calcarifer. Similarly, Mao et al. (1999) reported the isolation of the Redwood Park virus (RPV) from red-legged frogs Rana aurora and stickleback fish Gasterostelus aculeatus. Interestingly, 1 putative iridovirus is known to infect the freshwater snail species Lymnaea truncatula (Rondelaud \& Barthe 1992), and macroinvertebrate surveys have identified this genus of snail to be present in the Kootenai River system (C. Holderman, KTOI, pers. comm.).

In summary, results presented here demonstrate that WSIV is easily transmitted horizontally and that this may be the primary mode of transmission in the Kootenai River system. WSIV appears to be endemic in the Kootenai River system, and this study suggests that a pathogen-free water supply could minimize the risk of WSIV outbreaks in cultured white sturgeon. Because WSIV infection is frequently identified from progeny reared at the KTOI hatchery, it was believed that adults were carriers of WSIV and that vertical transmission was playing a role in the spread of this virus. This was not shown to be the case in this study, but the ability of this virus to be transmitted vertically is still in question. If vertical transmission does occur among Kootenai River white sturgeon, it does not occur in all cases. The absence of WSIV infection in fish reared on municipal water demonstrates a lack of vertical transmission and shows that not all wild adults will yield virus-positive progeny following spawning. This may have important management implications for resource managers and aquaculture facilities. If virusfree broodstock can be selected and their progeny reared on a virus-free water source, disease outbreaks associated with WSIV could be minimized.
Acknowledgements. This project was funded through the Kootenai Tribe of Idaho and the Bonneville Power Administration (BPA Project Number 198806400). We thank the staff at the Electron Microscopy Center, Washington State University, for their expertise as well as the Histopathology staff at the Washington Animal Disease and Diagnostic Laboratory. We also thank the KTOI Hatchery staff (C. Lewandowski, R. Aitken, E. Wagner, and R. Bahe) for their technical support during the spawning and rearing of fish. Finally, the excellent maintenance of the experimental fish at the UI by A. Carlson is acknowledged.

\section{LITERATURE CITED}

Amend DF, Pietsch JP (1972) Virucidal activities of two iodophors to salmonid viruses. J Fish Res Board Can 29:61-65

Arimoto M, Sato J, Maruyama K, Mimura G, Furusawa I (1996) Effect of chemical and physical treatments on the inactivation of striped jack nervous necrosis virus (SJNNV). Aquaculture 143:15-22

Bootland LM, Dobos P, Stevenson RMW (1991) The IPNV carrier state and demonstration of vertical transmission in experimentally infected brook trout. Dis Aquat Org 10:13-21

Bullock GL, Rucker RR, Amend D, Wolf K, Stuckey HM (1976) Infectious pancreatic necrosis: transmission with iodinetreated and nontreated eggs of brook trout (Salvelinus fontinalis). J Fish Res Board Can 33:1197-1198

Cipriano RC, Novak BM, Flint DE, Cutting DC (2001) Reappraisal of the federal fish health recommendation for disinfecting eggs of Atlantic salmon in iodophor. J Aquat Anim Health 13:320-327

Drennan JD, Ireland S, LaPatra SE, Grabowski L, Carrothers T, Cain KD (2005) High density rearing of white sturgeon (Acipenser transmontanus) induces white sturgeon iridovirus disease among asymptomatic carriers. Aquac Research 36:824-827

Georgiadis MP, Hedrick RP, Johnson WO, Yun S, Gardner IA (2000) Risk factors for outbreaks of disease attributable to white sturgeon iridovirus and white sturgeon herpesvirus-2 at a commercial sturgeon farm. Am J Vet Res 61:1232-1240

Georgiadis MP, Hedrick RP, Carpenter TE, Gardner IA (2001) Factors influencing transmission, onset and severity of outbreaks due to white sturgeon iridovirus in a commercial hatchery. Aquaculture 194:21-35

Goldes SA, Mead SL (1995) Efficacy of iodophor disinfection against egg surface-associated infectious hematopoietic necrosis virus. Prog Fish-Cult 57:26-29

Grotmol S, Totland GK (2000) Surface disinfection of Atlantic halibut Hippoglossus hippoglossus eggs with ozonated sea-water inactivates nodavirus and increases survival of the larvae. Dis Aquat Org 39:89-96

Hedrick RP, Groff JM, McDowell TS, Wingfield WH (1990) An iridovirus infection of the integument of the white sturgeon Acipenser transmontanus. Dis Aquat Org 8:39-44

Hedrick RP, McDowell TS, Groff JM, Yun S, Wingfield WH (1992) Isolation and some properties of an iridovirus-like agent from white sturgeon Acipenser transmontanus. Dis Aquat Org 12:75-81

LaPatra SE, Groff JM, Jones GR, Munn B, Patterson TL, Holt RA, Hauck AK, Hedrick RP (1994) Occurrence of white sturgeon iridovirus infections among cultured white sturgeon in the Pacific Northwest. Aquaculture 126:201-210

LaPatra SE, Groff JM, Patterson TL, Shewmaker WD, Casten M, Siple J, Hauck AK (1996) Preliminary evidence of sturgeon density and other stressors on manifestation of white sturgeon iridovirus disease. J Appl Aquac 6:51-58 
LaPatra SE, Ireland SC, Groff JM, Clemens KM, Siple JT (1999) Adaptive disease management strategies for the endangered population of Kootenai river white sturgeon. Fisheries 24:6-13

Mao J, Green DE, Fellers G, Chinchar VG (1999) Molecular characterization of iridoviruses isolated from sympatric amphibians and fish. Virus Res 63:45-52

Moody NJG, Owens L (1994) Experimental demonstration of the pathogenicity of a frog virus, Bohle iridovirus, for a fish species, barramundi Lates calcarifer. Dis Aquat Org 18: 95-102

Rondelaud D, Barthe D (1992) Observations epidemiologiques sur l'iridovirose de Lymnaea truncatula, mollusque

Editorial responsibility: Jo-Ann Leong,

Kaneohe, Hawaii, USA vecteur de Fasciola hepatica. CR Acad Sci Paris Ser III 314: $609-612$

Watson LR, Groff JM, Hedrick RP (1998) Replication and pathogenesis of white sturgeon iridovirus (WSIV) in experimentally infected white sturgeon Acipenser transmontanus juveniles and sturgeon cell lines. Dis Aquat Org 32:173-184

Wolf K (1988) Fish viruses and fish viral diseases. Cornell University Press, Ithaca, NY

Yesaki TY, Ek R, Siple J, Van Eenennaam JP, Doroshov SI (2002) The effects of iodophor disinfection and transportation on the survival to hatch of fertilized white sturgeon (Acipenser transmontanus) eggs. J Appl Ichthyol 18:639-641

Submitted: July 15, 2005; Accepted: February 8, 2006

Proofs received from author(s): May 19, 2006 